\title{
The Evolution of Party Policy and Cleavage Voting under Power-Sharing in Northern Ireland
}

\author{
James Tilley ${ }^{1 \star}$, John Garry ${ }^{2}$ and Neil Matthews ${ }^{3}$ \\ ${ }^{1}$ Department of Politics and International Relations, University of Oxford, Oxford, UK, ${ }^{2}$ Department of \\ Politics, University of Belfast, Belfast, UK and ${ }^{3}$ School of Sociology, Politics and International Studies, \\ University of Bristol, Bristol, UK \\ ${ }^{*}$ Corresponding author. Email: james.tilley@politics.ox.ac.uk
}

(Received 8 February 2019; revised 30 April 2019; accepted 20 May 2019;

first published online 10 July 2019)

\begin{abstract}
This article argues that post-conflict consociational arrangements in ethnically divided societies incentivize moderation by political parties, but not policy differentiation outside the main conflict. This results in little policy-driven voting. Analysing party manifestos and voter survey data, we examine the evolution of party policy and cleavage voting under power-sharing in Northern Ireland 1998-2016. We find a reduction in ethnonational policy differences between parties and that ethno-nationalism has become less important in predicting vote choice for Protestants, but not Catholics. We also find little party differentiation in other policy areas and show that vote choices are largely independent of people's policy stances on economic or social issues. Our findings are thus largely consistent with a 'top-down' interpretation of political dynamics.
\end{abstract}

Keywords: voting; power-sharing; consociation; ideology; parties; Northern Ireland

The Northern Ireland Assembly and power-sharing executive have now been in place, albeit not in continuous operation, for over 20 years. In the early years of power-sharing opinion was divided as to how the new consociational institutions would shape party politics and voter behaviour. Some argued that the new rules of the game would almost inevitably lead to increased 'ethnic outbidding' (Dixon 2002; Taylor 2001; Wilford 2001). This perspective emphasized that consociational power-sharing would incentivize party competition within the unionist and nationalist blocs, with competition focused on the underlying ethno-national dimension. This dynamic would polarize the parties and, ultimately, voters. Consociational power-sharing was thus a recipe for political instability.

Others argued that the proportional electoral system used in Assembly elections and the incentivized collaboration of parties in government would lead to a moderation of party positions on the main ethno-national dimension and potentially

(C) The Authors 2019. Published by Government and Opposition Limited and Cambridge University Press. This is an Open Access article, distributed under the terms of the Creative Commons Attribution licence (http://creativecommons. org/licenses/by/4.0/), which permits unrestricted re-use, distribution, and reproduction in any medium, provided the original work is properly cited. 
more competition among parties on other issues (McGarry and O'Leary 2004, 2009; O'Leary 1999, 2001). The consociational institutions would do what they were meant to do: facilitate elite cooperation within blocs and between blocs. This cooperation would then lead to policy moderation by parties within the two opposing blocs on the dominant ethno-national dimension and allow the emergence of competition within blocs on economic and social policy. Put together, consociationalism promised a more stable future with parties working together and more 'bread and butter' politics within each bloc, even if the two communities remained distinct.

Which of these perspectives proved more accurate? And how does the example of Northern Ireland help us to understand, more generally, the effect of consociational institutions on political competition? We are not the first to try and answer these questions. Yet much of the previous work on party competition and electoral behaviour under power-sharing in Northern Ireland examines the years immediately after the institutions came into play, especially the first two elections, in 1998 and 2003 (Mitchell and Tilley 2004; Mitchell et al. 2001, 2009; Tilley et al. 2008). Although clearly valuable in documenting the transition to power-sharing, data from this early period tell us little about the long-term effect of those institutions on parties and voters. Moreover, these articles, and subsequent research that covers later elections (Garry 2016; Gormley-Heenan and Macginty 2008; McGlynn et al. 2014; Moore et al. 2014), have not systematically measured party positions. Equally, voter behaviour has not been analysed on a range of policy areas.

This article rectifies all three of these deficiencies. We examine voters and parties over the long term from 1998 until 2016, we systematically measure party positions using manifesto data, and we look at the full range of policy areas for both parties and voters. The combination of voter data and party data enables us to examine fully the links between party policy and voter behaviour. This comprehensive assessment of how parties and vote choice have evolved in Northern Ireland helps us to understand the impact of power-sharing on party competition and electoral behaviour. Our findings reveal that the consociational optimists were largely, but not wholly, right. Party competition on the ethno-national policy dimension within the unionist bloc (between the Democratic Unionist Party (DUP) and the Ulster Unionist Party (UUP)) has decreased substantially. As a consequence of this, voters for the two main unionist parties look much more similar in terms of their ethno-national ideology. Within the nationalist bloc, party positions have converged somewhat, but voter choice remains largely centred on ethnonationalism. Nonetheless, there has been no increase in polarization between the two nationalist parties, Sinn Féin and the Social Democratic and Labour Party (SDLP). In that sense, consociation does not appear to have polarized parties and voter choices, and for unionists it has done the exact opposite. Yet we also find little evidence that parties are competing for votes on other dimensions either in terms of their positions or voters' choices. This is consistent with work that argues that power-sharing encourages valence politics within blocs: competition focused on who can deliver for their community (Mitchell et al. 2009).

The article proceeds as follows. First, we discuss the competing theoretical accounts of the impact of power-sharing in Northern Ireland on party strategy and voter choice. Second, we describe our data on party positions drawn from a bespoke analysis of party manifestos between 1998 and 2016 and from survey 
data on voter positions and vote choices in 1998 and 2016. Third, we show how parties have altered their positions over time and report on a series of models that use the ideological positions of voters to predict vote choice. Finally, we conclude by discussing the implications of our results for consociational theory, topdown models of voter behaviour and the future of Northern Irish politics.

\section{The consequences of consociation}

The ethnic outbidding interpretation of party competition in deeply divided polities predicts that parties adopt ever more extreme policy positions and generate a polarized and unstable party system (Horowitz 1985; Rabushka and Shepsle 1972). Fully mobilized ethnic party systems are made up of parties that appeal to one ethnic group and elections that resemble an ethnic headcount. Within each ethnic bloc, party competition takes the form of parties seeking to 'outbid' each other with ever more hard-line policy stances on the dominant ethnic dimension. Voters respond to these platforms. Their choice between parties within their bloc is based on the strength of their ethnic identity; and attitudes towards economic or social policy are largely irrelevant.

As Christina Zuber (2012, see also Chandra 2005 and Coakley 2008) points out, outbidding requires a highly segmented party system and a distribution of voters on the main dimension which is closer to polarized than normal. This portrait broadly matches the historical situation in Northern Ireland, and some party changes in the 20th century look like successful cases of outbidding. For example, John Coakley (2008) and Paul Mitchell (1995) argue that the changing pattern of party support from the 1970s onwards shows the reality of ethnic outbidding (albeit affected by the relevant electoral system). Bernadette Hayes and Ian McAllister also point to the 'almost complete replacement of the Irish Parliamentary Party by Sinn Féin in 1918, and the Nationalist Party by the SDLP in 1970' as examples of the 'cyclical nature of the process and how rapid the turnover can be' (Hayes and McAllister 2013: 142). Nonetheless there is also long-standing evidence for cross-cutting cleavages within the two blocs, particularly for unionists, which suggests that policy preferences outside the ethno-national arena may also be important. For example, Geoffrey Evans and Mary Duffy (1997) showed that there was an economic leftright cleavage for unionist voters in the 1980s and 1990s, and Tilley et al. (2008) find a weaker echo of that for nationalists. Linked to this qualification on bloc solidarity is the influence of social class on voting: both the UUP and SDLP are typically found to have a more middle-class voter base (Evans and Tonge 2009; Hayes and McAllister 2013; McAllister 1983). Equally, there is tentative evidence that party support in the past was driven by people's views on 'moral' issues such as abortion rights and same-sex marriage (Mitchell and Tilley 2004).

How did the implementation of the 1998 Agreement affect party policy positions and voter decision-making? The 1998 Agreement is, almost without exception, accepted as a consociational settlement (Horowitz 2001; McGarry and O'Leary 2004, 2006a, 2006b, 2009; O'Leary 2001). It established a legislature elected using the single transferable vote electoral system in conjunction with a sequential divisor portfolio allocation mechanism (d'Hondt) to generate an inclusive large coalition government (O'Leary et al. 2005). The agreement explicitly recognized the two 
principal communities in Northern Ireland: unionists and nationalists. Elected Members of the Assembly (MLAs) identify as nationalist, unionist or other. Some legislation requires a concurrent majority among nationalists and unionists for passage, and a trigger procedure can be invoked by a minority of MLAs to oblige normal decision-making to be passed with cross-community consent.

Many argued in the early days of power-sharing in Northern Ireland that political polarization would increase (Dixon 2002; Oberschall and Palmer 2005; O'Flynn 2003; Taylor 2001, 2006; Wilford 2001). This was partly because consociation was expected to entrench and reinforce existing divisions, but it was also a prediction about future party strategy. Since the two major blocs are institutionalized, the arrangements benefit the party most strongly associated with each ethnic bloc: the most extreme party. Moreover, the extreme parties are incentivized to increase the salience of the ethno-national dimension, forcing other parties to compete on that dimension. This means that voters pay less attention to other policy areas and there is uni-dimensional party competition on the ethno-national cleavage within blocs.

Others, however, saw consociation as a route to moderation, arguing that the form of consociation in Northern Ireland undermines the rationale for outbidding (McGarry and O'Leary 2004, 2009; O'Leary 1999, 2001; for a recent update see McCrudden et al. 2016). Power-sharing in Northern Ireland creates strong incentives for parties to take their proportional share of ministerial portfolios, which means that radicals are not outside the tent 'creating a polarized atmosphere that pressurizes moderates and makes compromise difficult' (McGarry and O'Leary 2009: 599). Rather, radical parties expand their support at the expense of moderate parties, while at the same time becoming more like the moderate parties they replace (McGarry and O'Leary 2004; Mitchell et al. 2001).

Moreover, the institutional set-up can be seen as erecting barriers to new parties which challenge the status quo using an outbidding strategy, while also allowing new cleavages between existing parties to emerge. As John McGarry and Brendan O'Leary (2004: 344) argued a few years after the Good Friday Agreement: 'If Northern Ireland's Agreement can be consolidated, there is a much greater likelihood of debate on socio-economic and related issues than existed in the political vacuum that preceded devolution.' Party competition within blocs may move away from just the ethno-national dimension. Mitchell et al. (2009) develop this idea by arguing that these incentives for moderation lead to 'ethnic tribune' parties. Parties within a bloc do not compete on new economic or social policy positions, but rather as champions of their community in the crosscommunity power-sharing executive. Party policy positions become similar, and policy distinctions - because they are increasingly minimal - become irrelevant to voters when they decide their vote.

We are not the first to try and adjudicate between the argument that consociation leads to polarization and the argument that it leads to moderation. There were a number of important empirical studies in the immediate aftermath of the 1998 and 2003 Assembly elections (Mitchell et al. 2009; Mitchell and Evans 2009; Tilley et al. 2008) and there has been work looking at some of the more recent elections as well (Coakley 2008; Garry 2016; Gormley-Heenan and Macginty 2008; McGlynn et al. 2014; Moore et al. 2014). Yet there is little research which includes 
the most recent period of functioning power-sharing: 2011-16. Here we take the longer view by looking at the entire 1998-2016 period of power-sharing. We are thus able to assess the long-term effect of institutional change on party and voter choices. Moreover, there is still disagreement on whether parties and electorates have polarized or moderated, and, if so, when that happened. Indeed, there is no consensus that these two things have even occurred together. Stephen Farry (2009) argues that party politics became more polarized after the 1998 Agreement, but that the electorate became more moderate, or at least no more extreme. Similarly, previous findings on cleavage change at the voter level have been mixed. For example, while some work has suggested that cross-cutting cleavages within blocs disappeared (Tilley et al. 2008), there is also evidence that crosscutting cleavages emerged after 1998 (Mitchell and Tilley 2004).

There are two main reasons for these disagreements. One relates to party positions, the other to voter decisions. Party positions are not easy to measure. Most authors describe specific policies and stances that parties adopt and how these compare to other specific policies before the Good Friday Agreement (see for example Moore et al. 2014). This can be illuminating, but by its very nature it provides a partial, and fragmented, view of the ideological movements of parties. Here we aim systematically to measure party positions on multiple dimensions of potential policy conflict over the entire period of the Agreement. The second difficulty relates to how we look at cleavage politics within the electorate. Much of the existing work focuses on aggregate statistics of support for extreme positions, but the crucial test is really whether policy divisions within the electorate are translated into policydriven voting. Here we look at multiple potential policy dimensions in models of vote choice at elections. Thus, we aim to assess fully how party policy, in all its types, has changed since the advent of the Agreement and how voters' choices have, or have not, been shaped by the parties' movements.

\section{Methods and data \\ Measuring party positions}

There is much debate as to the best way to estimate the policy positions of political agents. Expert surveys, ${ }^{1}$ roll-call analysis and voter estimates all have advantages (Laver 2001). Here we focus on manifesto analysis, which is best for our purposes since manifestos represent party policy in a comparable manner across parties and across time. Manifestos are substantive documents: they elaborate the core policy and programmatic statements of parties. And while few voters actually read them, they are extensively distributed and commented on by the media (Laver and Garry 2000).

We use every manifesto of the four major Northern Ireland parties published at each of the five Assembly elections between 1998 and 2016 to estimate party positions on three major policy dimensions: ethno-national; economic left-right; and social liberal-conservative. We also include the 2011 and 2016 manifestos of Traditional Unionist Voice (TUV), a small unionist party which emerged from a 2007 split in the DUP. We use a specially constructed coding frame for the Northern Ireland context which facilitates coding on the underlying ethno-national 
dimension of policy as well as coding on a range of generic policy dimensions (economic, moral, environmental, and so on). The precise coding details are in online Appendix 1. These manifesto data provide, first, a measure of policy salience: the proportion of the quasi-sentences in each manifesto that discuss a specific issue. Second, they give us a measure of policy position, namely, the net score of pro and anti- sentences.

\section{Measuring voter positions and choices}

More straightforward, although by no means trivial, is the measurement of voter positions and vote choice. The data we use here are high-quality face-to-face surveys carried out in 1998 and 2016 following the Assembly elections. Both surveys used a mock ballot for the vote question, allowing us to measure vote choices directly. ${ }^{2}$ Both surveys included identical, or very similar, questions that can be scaled to give measures of underlying values that relate directly to the three dimensions of party competition already discussed: ethno-nationalism, economic left-right and social liberalism-conservativism. Full details of these scales are in online Appendix 2.

Our models predict first preference vote choice at the Assembly election in 1998 and 2016, excluding non-voters and votes for the smallest parties. We separate Protestants and Catholics as most essentially vote within two different party systems. Religion is measured with reference to people's own self-professed religion and the religion that they were brought up in. Only 5\% of people in 2016 were classified as having no religion along with another $1 \%$ that identified as a member of a non-Christian religion. These numbers were even lower in 1998. For Protestants we model vote choice between the two main unionist parties, the DUP and UUP, as well as Alliance, other unionist parties ${ }^{3}$ (in 1998) and the TUV (in 2016). For Catholics we model vote choice between the main nationalist parties, Sinn Féin and the SDLP, as well as Alliance and grouped leftist parties ${ }^{4}$ (in 2016). We exclude the extremely small number of Protestants (3\% in 2016) who gave their first preference vote to a nationalist party and the equally small number of Catholics ( $4 \%$ in 2016) who gave their first preference vote to a unionist party.

The models contain a number of social characteristics as control variables. Many of these might be thought of as precursors to the three ideological positions and therefore of less interest when we want to assess policy voting. As elsewhere, occupational social class is a strong predictor of people's left-right position and education is a strong predictor of social liberalism (Hayes and McAllister 1995). It is important to control for these variables, however, as they can also have more direct effects. For example, some parties are perceived as more working class, perhaps because of their history, and that might directly attract working-class voters. Birth cohort also has a powerful direct effect on vote choice in Northern Ireland, with newer generations more likely to support the DUP and Sinn Féin (Hayes and McAllister 1999, 2013; Tilley and Evans 2011; Tonge et al. 2011). Since generation is correlated with social liberalism in Northern Ireland (Evans and Tonge 2016), it is important to hold this constant. We include categorical measures of educational qualification, occupational social class, birth cohort, gender, church attendance and church denomination (for Protestants). In general, we find similar 
effects of social bases on party support as those found by Hayes and McAllister (2013), and the inclusion of social characteristics in the models makes little difference to the effects of people's ideology on vote choice.

\section{Analysis}

\section{The ideological movement of parties}

How has party ideology changed? Figure 1 shows the positions of the main four parties in terms of the central ethno-national dimension. Here we simply show the percentage of codable sentences in the manifestos that are devoted to either unionist or nationalist sentiments. There is no need to calculate a 'net' score, because the DUP, UUP and TUV never use nationalist sentences and the SDLP and Sinn Féin never use unionist sentences. ${ }^{5}$ Scores far above zero indicate a high proportion of sentences that are unionist, scores far below zero indicate a high proportion of sentences that are nationalist. There has clearly been convergence as all parties have reduced discussion of the core ideological divide. This,

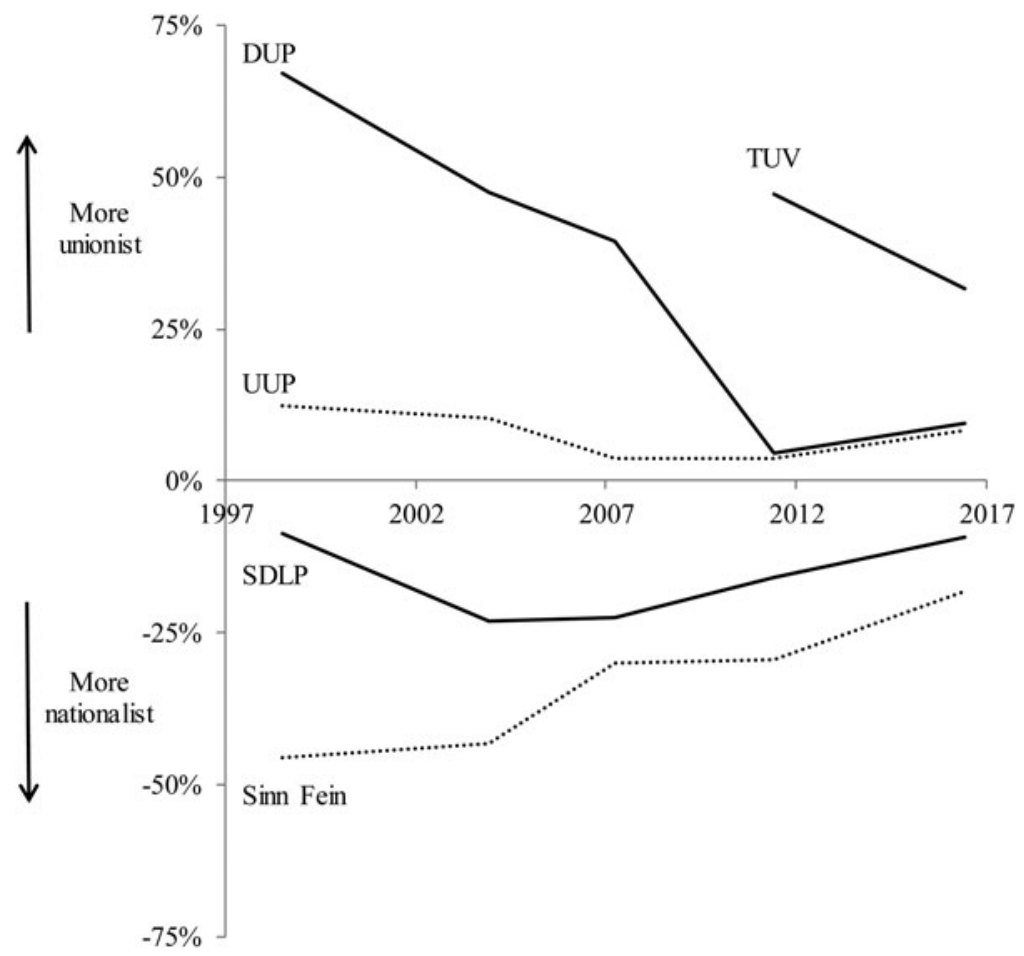

Figure 1. Percentage of Sentences in Party Manifestos that Are Unionist or Nationalist

Source: Combined Northern Ireland party manifesto file.

Note: The percentage of sentences for the three unionist parties refers to the proportion of codable sentences that are unionist; the percentage of sentences for the two nationalist parties refers to the proportion of codable sentences that are nationalist. 
perhaps surprisingly, is much more evident for the DUP than any other party. In 1998 nearly three-quarters of codable sentences in the DUP manifesto referred to unionism. By 2016, the same calculation is less than $10 \%$. Moreover, the gap between the DUP and the UUP fell to zero in 2011 and has remained there since. ${ }^{6}$ On the nationalist side, this pattern of convergence is also present, but is weaker. Sinn Féin and the SDLP were more similar in 1998 than were the DUP and UUP, and there remains a gap, albeit reduced in size, between the parties right up to 2016.

The only evidence of ethnic outbidding comes from the emergence of the TUV, which has positioned itself as a more unionist party than the DUP and UUP. Yet

\section{DUP}
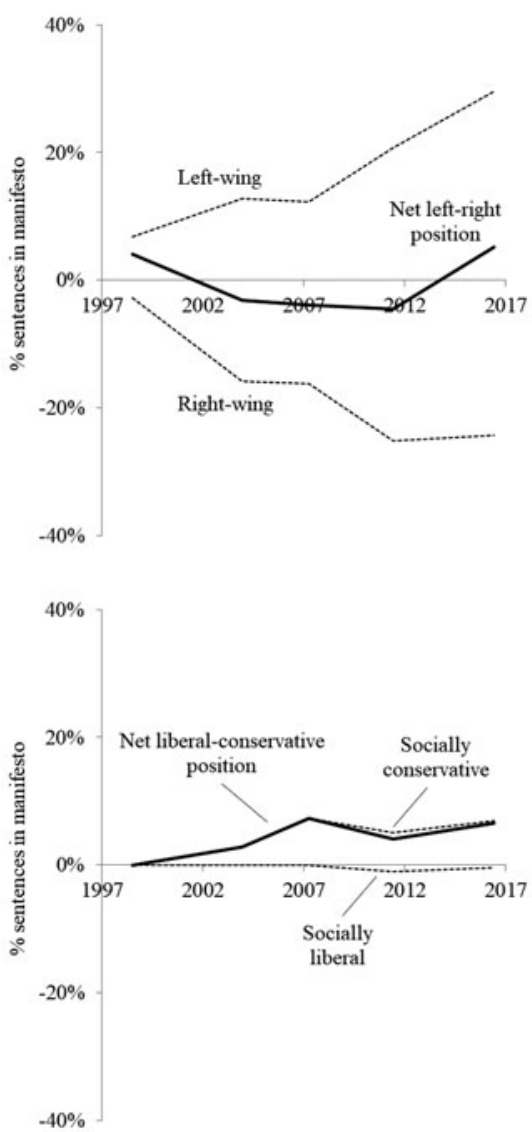

UUP
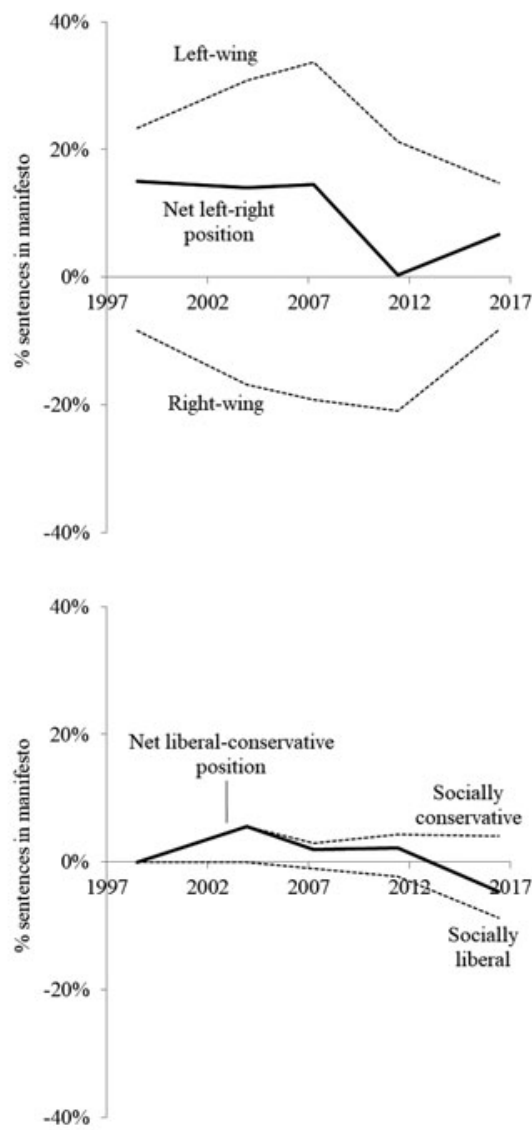

Figure 2. Ideological Positions of the Unionist Parties Source: Combined Northern Ireland party manifesto file. Note: The first two graphs show the percentage of codable DUP and UUP manifesto sentences that are economically left and right wing, and the net position of the parties. The second two graphs show the percentage of codable DUP and UUP manifesto sentences that are socially conservative and socially liberal, and the net position of the parties. 
this has proved to be a remarkably ineffective strategy in terms of electoral success. After splitting from the DUP in late 2007, the TUV has participated in three Assembly elections. In 2011 it received just $2.5 \%$ of first preference votes, in $20163.4 \%$ and in $20172.6 \%$. Bidding for votes on the extreme does not appear to have worked.

Overall, there has been a great deal of change in terms of ethno-national positioning, especially on the unionist side. But what about party positions on other more 'bread and butter' matters? Figure 2 shows the positions of the DUP and UUP on the left-right and liberal-conservative dimensions. These graphs show both salience and position. Take the top left graph for the DUP and left-right ideology. The top dotted line shows the number of sentences that are left wing, the bottom dotted line shows the number of sentences that are right wing and the thick black line shows the net position, which is the number of left-wing sentences minus the number of right-wing sentences. ${ }^{7}$ The net position changes remarkably little over time, but the number of left-right statements increases a great deal. In 1998 less than $10 \%$ of the manifesto was devoted to left-right economic issues; by 2016 over half of the codable sentences in the DUP manifesto were about left-right issues. The UUP's net left-right position shown in the top right graph also remains fairly similar over time, but the salience of these issues changes much less than for the DUP. The UUP looks a little more left wing than the DUP since the Agreement, but it is notable how these changes are relatively small compared with the ethno-national dimension. Both parties also have a fairly mixed position - neither is producing exclusively left or right policy positions.

The bottom two graphs show the parties' statements about liberal-conservative issues. ${ }^{8}$ While neither party focuses on these issues a great deal, there is a relatively consistent difference between the two that has grown slightly over time. Whereas the DUP manifestos almost never contain socially liberal sentences, the UUP position has become a little more socially liberal than the DUP over time.

Figure 3 shows the same graphs, but for the two nationalist parties. Both are clearly more left wing than the two unionist parties. Sinn Féin manifestos rarely have right-wing sentences, and there are normally more than three or four times as many left-wing sentences as right-wing sentences in the SDLP manifestos. There is a gap between the parties, but it is small and changes little. The bottom two graphs show the liberal-conservative dimension. Neither Sinn Féin nor the SDLP focus on this very much, but Sinn Féin is slightly more socially liberal than the SDLP.

In summary, the main change to party positioning has been the enormous convergence between the DUP and UUP in terms of their professed unionism. The DUP has stopped talking about unionism and started talking about economic left-right policy, but not in a consistent left or right way. Although there has also been convergence of the two nationalist parties on the ethno-national dimension, it is less pronounced than for the unionists. Moreover, while there have been other small changes in party positions on both sides, the real pattern elsewhere is of continuity rather than change. Overall, parties have converged on more moderate ethno-national positions, but at the same time there is little evidence of other policy dimensions becoming more divisive. 
Sinn Féin
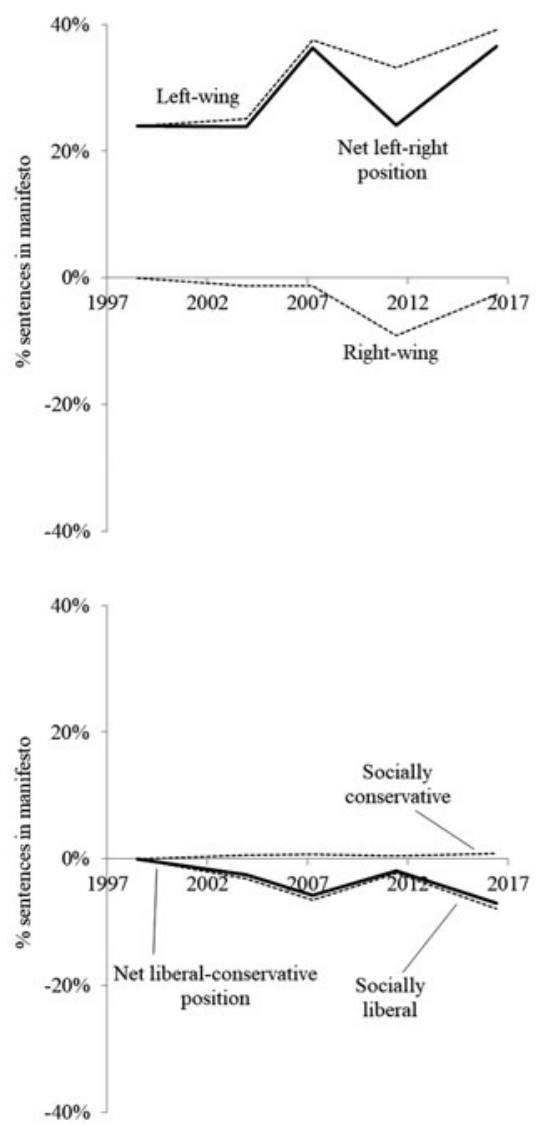

$S D L P$
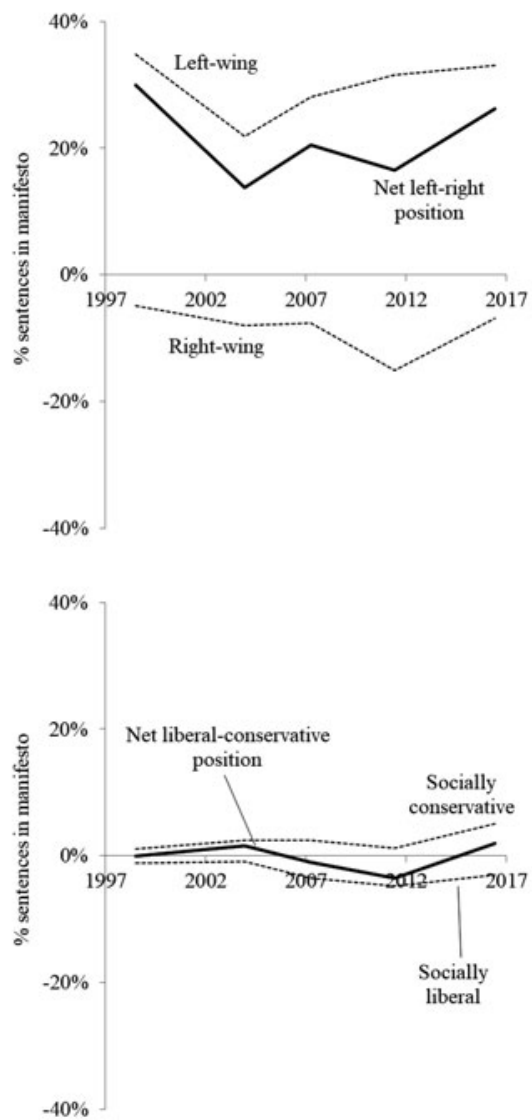

Figure 3. Ideological Positions of the Nationalist Parties Source: Combined Northern Ireland party manifesto file.

Note: The first two graphs show the percentage of codable Sinn Féin and SDLP manifesto sentences that are economically left and right wing, and the net position of the parties. The second two graphs show the percentage of codable Sinn Féin and SDLP manifesto sentences that are socially conservative and socially liberal, and the net position of the parties.

\section{Vote choice and ideology}

The next step of our analysis is to look at how the influence of ideology on vote choice has changed. Figure 4 shows predicted probabilities from multinomial models of first preference vote choice in 1998 and 2016 for Protestants. ${ }^{9}$ The light grey bars represent people with less unionist views (specifically one standard deviation below the mean on the unionism scale) and the black bars represent people with more unionist views (one standard deviation above the mean). As discussed, the models also include left-right and liberal-conservative ideology as well as a number of social characteristics. ${ }^{10}$ The full tables of coefficients for all models discussed here are in online Appendix 3. If we look at the impact of unionist views on first preference 
1998

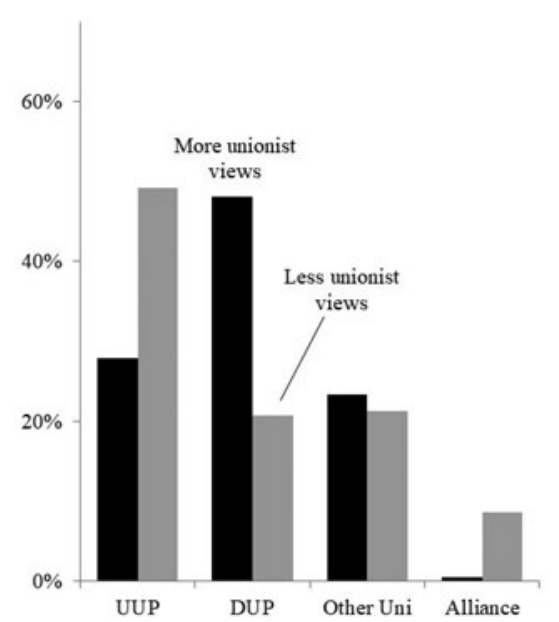

2016

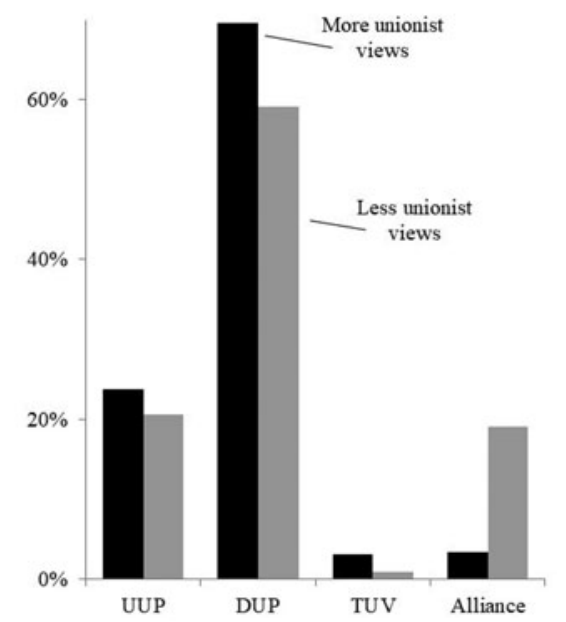

Figure 4. Predicted Probabilities of First Preference Voting of Protestants by Ethno-National Position

Source: 1998 Northern Ireland Assembly Election Study and 2016 Northern Ireland Assembly Election Study. Note: These graphs show predicted probabilities from multinomial logistic regression models of Protestants' first preference vote in the 1998 and 2016 Northern Ireland Assembly elections. Unionism is measured using three questions: strength of unionist identity, attitudes towards parades and attitudes towards the IRA. 'More unionist views' are scores one standard deviation above the mean and 'less unionist views' are scores one standard deviation below the mean. The models hold constant birth cohort, gender, educational qualifications, occupational social class, church attendance, denominational affiliation, economic left-right values and social liberal-conservative values.

voting for the two main parties in Figure 4, the degree of change is remarkable. In 1998, people with more unionist views were twice as likely to give a first preference for the DUP rather than the UUP, and people with less unionist views were more than twice as likely to give a first preference to the UUP than the DUP. In 2016, the DUP is more popular generally, but the effect of unionism when comparing UUP to DUP voters is negligible (and not statistically significant). This fits neatly with what we saw in terms of the party movements. As the two unionist parties have converged on the ethno-national dimension, ethno-national policy positions have become irrelevant for voters deciding between the unionist parties.

No similar convergence is seen among Catholic voters. Figure 5 shows predicted probabilities of first preference vote choice for Catholics in 1998 and $2016 .{ }^{11}$ The light grey bars this time represent people with less nationalist views (specifically one standard deviation below the mean on the nationalism scale) and the black bars represent people with more nationalist views (one standard deviation above the mean). Nationalism is a very strong predictor of first preference vote choice in both 1998 and 2016. More people give Sinn Féin a first preference in 2016 than did in 1998, but the pattern of voting by nationalist sentiment is similar. People who are less nationalist give a first preference vote to the SDLP and Alliance; people who are more nationalist give a first preference vote to Sinn Féin. This is a little surprising as while the nationalist parties remained distinct in 2016 that distinctiveness had fallen compared with 1998. We discuss this finding further in the conclusion. 
1998

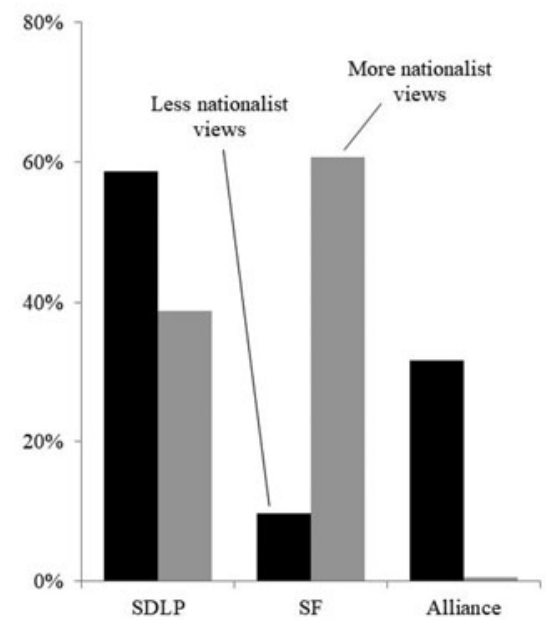

2016

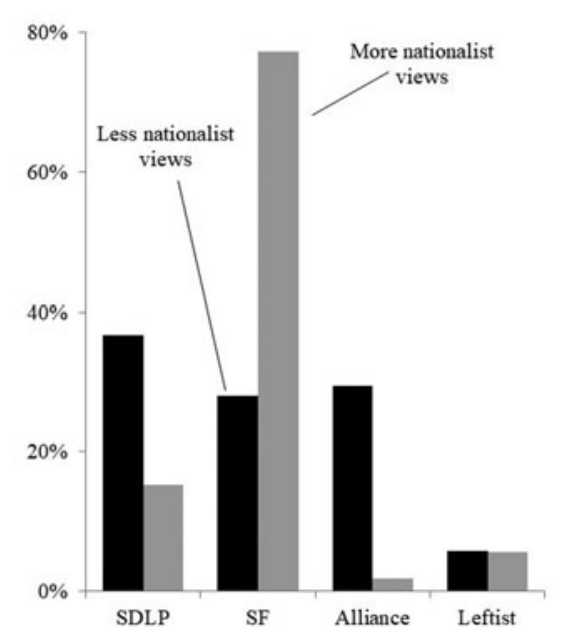

Figure 5. Predicted Probabilities of First Preference Voting of Catholics by Ethno-National Position Source: 1998 Northern Ireland Assembly Election Study and 2016 Northern Ireland Assembly Election Study. Note: These graphs show predicted probabilities from multinomial logistic regression models of Catholics' first preference vote in the 1998 and 2016 Northern Ireland Assembly elections. Nationalism is measured using three questions: strength of nationalist identity, attitudes towards parades and attitudes towards the IRA. 'More nationalist views' are scores one standard deviation above the mean and 'less nationalist views' are scores one standard deviation below the mean. The models hold constant birth cohort, gender, educational qualifications, occupational social class, church attendance, economic left-right values and social liberal-conservative values.

Figures 6 and 7 show the effects of people's placement on the other two ideological scales on first preference vote choices for Protestants and Catholics respectively. The light grey bars show predicted probabilities for more rightist and more conservative people (one standard deviation above the mean for each), and the dark bars predicted probabilities for more leftist and more liberal people (one standard deviation below the mean for each). Protestants are more likely to give a first preference vote to the DUP if they are leftist and socially conservative, but these are relatively small effects (although the differences between the UUP and DUP are all statistically significant at the 5\% level apart from left-right attitudes in 1998). There is also very little change over time. The parties have not really changed their positions on these secondary dimensions, and neither have voters' reactions to the parties. We see something extremely similar on the nationalist side. As Figure 7 shows, the effects of left-right and liberal-conservative attitudes have little effect on Catholic first preference voting. In fact, none of the coefficients for left-right and liberal-conservative ideology in either 1998 or 2016 is statistically significant at the 5\% level in predicting Sinn Féin, compared with the SDLP, first preference voting.

We thus find little evidence that other cleavages are more prominent in shaping voter behaviour in 2016 than in 1998 . This fits with the party movements. While parties now focus more on issues that are not ethno-national, they have not adopted particularly distinctive stances within their blocs. This means that the effects of economic left-right and social liberal-conservative ideological positions on people's vote choices have largely remained the same. 

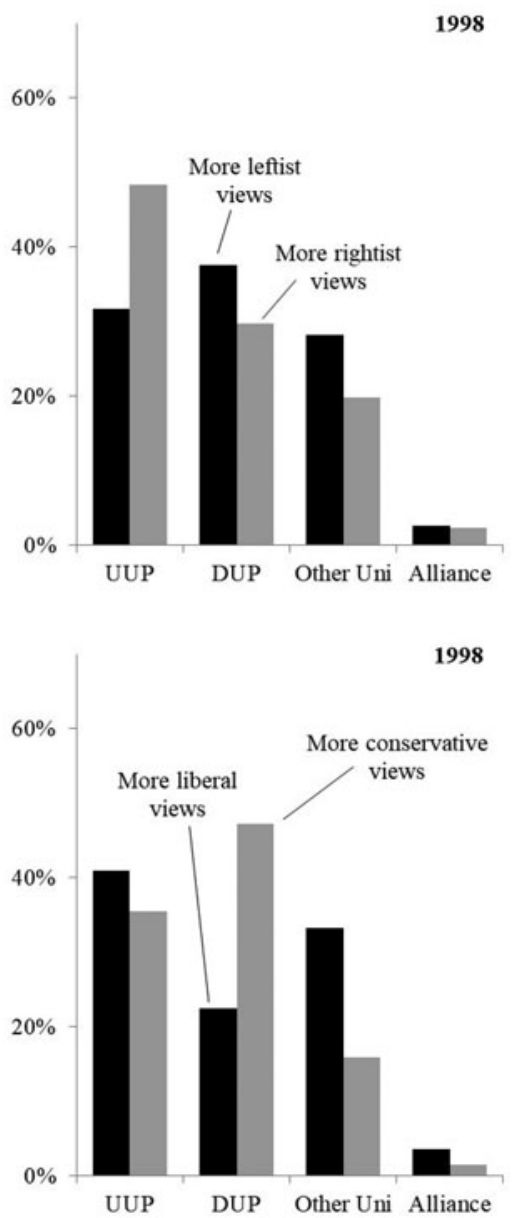
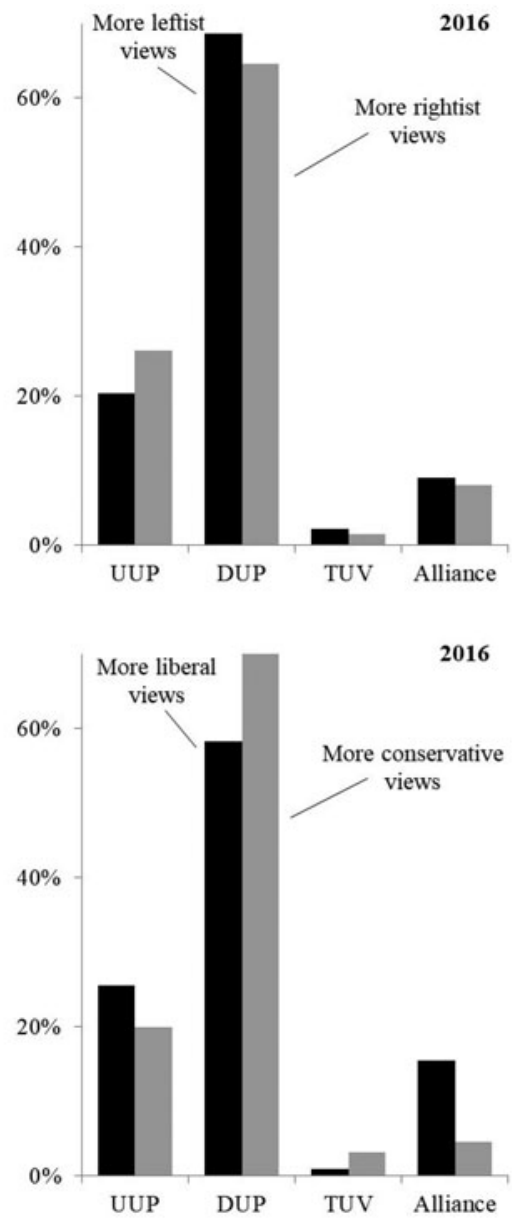

Figure 6. Predicted Probabilities of First Preference Voting of Protestants by Ideological Position

Source: 1998 Northern Ireland Assembly Election Study and 2016 Northern Ireland Assembly Election Study. Note: These graphs show predicted probabilities from multinomial logistic regression models of Protestants' first preference vote in the 1998 and 2016 Northern Ireland Assembly elections. The top two graphs show differences by economic left-right values. These are measured using five questions on state ownership, trade unions, private enterprise, redistribution and equality. 'More leftist views' are scores one standard deviation above the mean and 'more rightist views' are scores one standard deviation below the mean. The bottom two graphs show differences by social liberal-conservative values. These are measured using two questions on abortion rights and homosexuality. 'More liberal views' are scores one standard deviation above the mean and 'more conservative views' are scores one standard deviation below the mean. The models hold constant birth cohort, gender, educational qualifications, occupational social class, church attendance, denominational affiliation, ethno-national position and social liberalconservative values (top two graphs) or economic left-right values (bottom two graphs). 

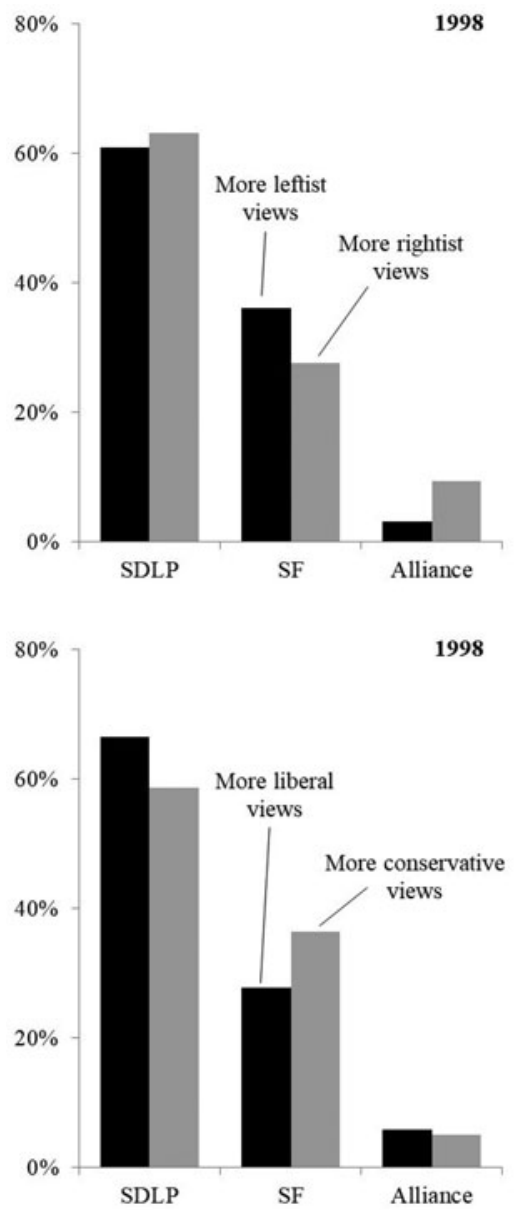
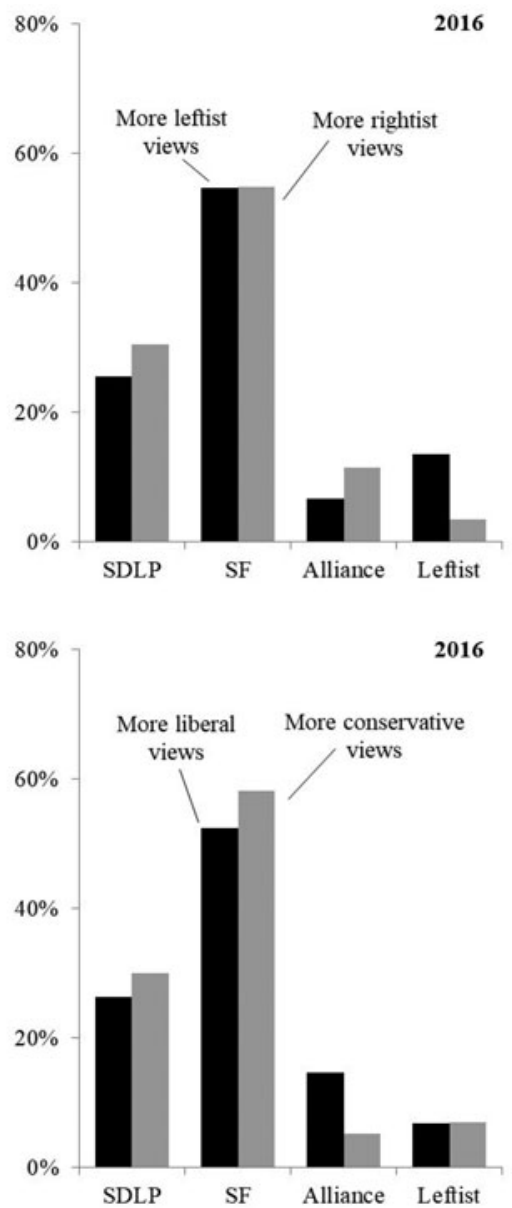

Figure 7. Predicted Probabilities of First Preference Voting of Catholics by Ideological Position Source: 1998 Northern Ireland Assembly Election Study and 2016 Northern Ireland Assembly Election Study. Note: These graphs show predicted probabilities from multinomial logistic regression models of Catholics' first preference vote in the 1998 and 2016 Northern Ireland Assembly elections. The top two graphs show differences by economic left-right values. These are measured using five questions on state ownership, trade unions, private enterprise, redistribution and equality. 'More leftist views' are scores one standard deviation above the mean and 'more rightist views' are scores one standard deviation below the mean. The bottom two graphs show differences by social liberal-conservative values. These are measured using two questions on abortion rights and homosexuality. 'More liberal views' are scores one standard deviation above the mean and 'more conservative views' are scores one standard deviation below the mean. The models hold constant birth cohort, gender, educational qualifications, occupational social class, church attendance, ethno-national position and social liberal-conservative values (top two graphs) or economic left-right values (bottom two graphs).

\section{Conclusions}

Our findings tell us something about politics in Northern Ireland, but also something about how parties react to institutional design and how voters react to party strategy. When people design institutions to address the problem of ethno-national conflict they clearly envisage that parties will change their behaviour and therefore 
the choices offered to voters will also change. The consociational institutions of Northern Ireland have meant that armed conflict has been swapped for portfolios and veto powers. This appears to have incentivized a reduction in the electoral salience of the ethno-national divide. There has been intra-bloc party convergence, although this is more pronounced within the unionist bloc, and these party movements seem to have been picked up by voters. In particular, the absence of policy division between the UUP and the DUP has led to a situation in which first preference voters for the two main unionist parties are almost identical in terms of their ethno-national position. This is important for interpreting Northern Irish politics and judging the impact of consociation. It suggests that the democratic structures of consociational power-sharing, perhaps especially those in Northern Ireland, do not facilitate ethnic outbidding and therefore polarization.

Yet while moderation on the main ethno-national policy dimension is clear, it has not been replaced by anything else. We see no evidence that peace and powersharing have led to the emergence of greater economic or social divisions within, let alone between, the blocs. O'Leary said in 1995 that 'when ethno-national communities feel secure, the pressure to sustain solidarity is reduced and the greater the likelihood that a more pluralist politics can emerge within them ... However, one must not exaggerate these possibilities' (O'Leary 1995: 713). He was right to add that disclaimer, as it has not come to pass. Parties may talk more about economic policy today, but within blocs they do not offer different policy programmes, and consequently voters do not appear to choose between parties on the basis of economic, or social, policy. ${ }^{12}$

These findings highlight a more general point: the centrality of parties in shaping voter behaviour from the top down. Just as in other democracies, and within the confines of the more 'normal' cleavage politics of class (Evans and Tilley 2017; Przeworski and Sprague 1986) and religion (Jansen et al. 2013), parties define the choices offered to voters and hence the active political cleavages within that society. Nonetheless this top-down model works considerably better for the unionist side. Why is there not similar convergence on the nationalist side? It may be the distinct historical trajectory of Sinn Féin, which emerged as the political arm of the main paramilitary republican movement, the IRA. The association between contemporary Sinn Féin and its violent past means that it has to work especially hard to persuade voters of its increased policy moderation. This distinction in the nationalist bloc between a violent (republican) and a constitutional (nationalist) approach to politics is largely absent in terms of differentiating the two main unionist parties (see Coakley 2008: 779 and Garry 2016 on asymmetries in the party system). These historical differences mean that voters may be less willing to update their views of the nationalist parties.

Leaving aside this asymmetry among voters, do our findings mean that the ethnic tribune argument (Mitchell et al. 2009) is right? Is it the case that policy positions are less relevant and people mainly vote for parties that they think best champion their community interests? The widespread disparities that were previously found between the parties in perceptions of their ability to defend their own community have certainly changed. Mitchell et al. (2009) note that large proportions of SDLP and UUP partisans in 2003 thought that their rival parties within their blocs were better at standing up for their own side of the ethnic-national divide. This is no longer the 
case. In 2016, only 14\% of SDLP first preference voters thought that Sinn Féin was better at representing Catholics than the SDLP, compared with $4 \%$ of Sinn Féin first preference voters who thought that the SDLP was better at representing Catholics. Equally, only 11\% of UUP first preference voters saw the DUP as better at representing Protestants, compared with $7 \%$ of DUP first preference voters who thought that the UUP was better at representing Protestants. Yet, this does not refute the Mitchell et al. (2009) claim as it could be seen as evidence of sorting: previously UUP voters who used to think the DUP was a better voice for Protestants have switched their vote to the DUP. Trying to test this argument outside an environment of rapid change is not easy, however. After all, most of the time people who vote for party $\mathrm{X}$ are unlikely to say that they think $\mathrm{X}$ does not defend the interests of their group. This is clearly an important area for future research, perhaps using experiments that prime identities to untangle the complex causal relationships between party preferences and perceptions of how parties look after different communities. Such work would help clarify what particular aspects of the unionist-nationalist distinction differentiate the parties in voters' minds.

Finally, we should emphasize that when talking of moderation and convergence, we are not suggesting that there are no serious policy disagreements between the hard-line parties from each bloc. Sinn Féin is more socially liberal, more economically left wing and more nationalist than the DUP. This has destabilized governance in Northern Ireland since the 2016 Assembly election. Disagreements persist on crucial policy issues, including an Irish Language Act and same-sex marriage, and new divisions around the Brexit negotiations have emerged since the 2017 general election (Tonge and Evans 2018). Regardless of what the future holds for power-sharing in Northern Ireland, our findings in the 1998-2016 period show that within each bloc there has been party moderation on the ethno-national dimension, but little increased division on other dimensions. The pronounced convergence of the two unionist parties has also meant that unionist voters of both parties look increasingly similar in terms of their ethno-national policy positions. The more general, and perhaps more important, lesson is that power-sharing institutions have an effect on party strategy and that party strategy in turn affects voter behaviour.

Supplementary information. To view the supplementary information for this article, please visit https:// doi.org/10.1017/gov.2019.20.

Author ORCIDs. (D) James Tilley, 0000-0002-1878-7628; John Garry 0000-0002-2089-3817.

Acknowledgements. The authors would like to acknowledge that research for this article was supported by the Economic and Social Research Council of the UK [ES/L005808/1]. The authors would also like to thank Brendan O'Leary for very helpful comments.

\section{Notes}

1 Examples of expert surveys including Northern Ireland are Benoit and Laver (2006) and the EPAC project (Edina and Zuber 2015).

2 With the partial exception of the 2003 Assembly Election Study survey, these are the only two election study surveys in the 1998-2016 period that facilitate direct comparability across time in terms of measures of voters on the core ideological attitude dimensions.

3 This group includes voters for the Progressive Unionist Party, the United Kingdom Unionist Party and the Ulster Democratic Party. 
4 This predominantly means those who voted for People Before Profit, but also people who voted for Labour (NI) and the Workers' Party. While these are formally non-aligned parties, they draw almost all their votes from Catholics.

5 In fact, the SDLP did have one unionist sentence in its 2003 manifesto (out of 564) and four sentences in its 2007 manifesto (out of 949), and the UUP had one nationalist sentence in its 2007 manifesto (out of 297), but correcting for these exceptions to the rule would make no difference to the patterns shown in Figure 1.

6 This suggests that the conclusion of Gormley-Heenan and Macginty (2008: 58) that on the unionist side there was 'evidence of a trend from outbidding to moderation, but this is best seen as a long and continuing process rather than an abrupt switch' now seems a little premature. Nonetheless our data concur with their central conclusion that 'the main ethno-national parties have moderated their stances on a range of issues' (Gormley-Heenan and Macginty 2008: 58).

7 In an attempt to simplify the data, these graphs do not therefore include 'centrist' economic sentences nor 'general' economic sentences. In practice, our coding gives very few centrist sentences in any manifesto and they make up under $1 \%$ of all coded sentences. Around 7\% of codable manifesto sentences also belong to a 'general' economic category with almost no variation over time or by party.

8 Conservative sentences are those that are morally conservative, authoritarian towards crime and punishment or anti-immigration. Liberal sentences are the opposite. Again 'centrist' and 'general' sentences are not shown, but in total they make up less than $1 \%$ of codable sentences for both the nationalist and unionist parties.

9 Unfortunately election surveys between 1998 and 2016 have not systematically carried questions that allow us to measure the location of voters on the different ideological dimensions. The 2003 election study is the most complete, but does not have questions that measure the liberal-conservative dimension and is missing the question on parades used to create ethno-national position. Nonetheless 2003 models that use a reduced version of the ethno-national measure and exclude the measure of social liberalism support our general findings. The full 2003 models are in online Appendix 4.

10 The two ideology scales are held at their means (for Protestants) to generate the predicted probabilities. Social characteristics are mainly held at their modal values.

11 Again the two ideology scales are held at their means (but this time the mean values for Catholics) to generate the predicted probabilities, and as before social characteristics are generally held at their modal values.

12 The evolution of the non-aligned parties also tends to support this conclusion. By far the best predictor of an Alliance vote for both Protestants and Catholics is ethno-national position in both 1998 and 2016. Perhaps the only evidence for greater pluralism is the 2016 success of People Before Profit which has a distinctive constituency of economically left-wing Catholics.

\section{References}

Benoit K and Laver M (2006) Party Policy in Modern Democracies. London: Routledge.

Chandra K (2005) Ethnic Parties and Democratic Stability. Perspectives on Politics 3(2), 235-252.

Coakley J (2008) Ethnic Competition and the Logic of Party System Transformation. European Journal of Political Research 47(6), 766-793.

Dixon P (2002) Northern Ireland: The Politics of War and Peace. Basingstoke: Palgrave.

Edina S and Zuber CI (2015) EPAC - A New Dataset on Ethno-nationalism in Party Competition in 22 European Democracies. Party Politics 21(1), 153-160.

Evans G and Duffy M (1997) Beyond the Sectarian Divide: The Social Bases and Political Consequences of Nationalist and Unionist Party Competition in Northern Ireland. British Journal of Political Science 27 (1), 47-81.

Evans G and Tilley J (2017) The New Politics of Class: The Political Exclusion of the British Working Class. Oxford: Oxford University Press.

Evans J and Tonge J (2009) Social Class and Party Choice in Northern Ireland's Ethnic Blocs. West European Politics 32(5), 1012-1030.

Evans J and Tonge J (2016) Partisan and Religious Drivers of Moral Conservatism: Same-Sex Marriage and Abortion in Northern Ireland. Party Politics, published early online, July, https://doi.org/10.1177/ 1354068816656665 . 
Farry S (2009) Consociationalism and the Creation of a Shared Future for Northern Ireland. In Taylor R (ed.), Consociational Theory: McGarry and O'Leary and the Northern Ireland Conflict. London: Routledge, pp. 165-179.

Garry J (2016) Consociation and Voting in Northern Ireland. Philadelphia: University of Pennsylvania Press.

Gormley-Heenan C and Macginty R (2008) Ethnic Outbidding and Party Modernization: Understanding the Democratic Unionist Party's Electoral Success in the Post-Agreement Environment. Ethnopolitics 7 (1), 43-61.

Hayes BC and McAllister I (1995) Social Class, Class Awareness and Political Beliefs in Northern Ireland and the Republic of Ireland. Economic and Social Review 26(4), 349-368.

Hayes BC and McAllister I (1999) Generations, Prejudice and Politics in Northern Ireland. In Heath A, Breen R and Whelan C (eds), Ireland, North and South: Perspectives from Social Science. Oxford: British Academy and Clarendon Press, pp. 457-491.

Hayes BC and McAllister I (2013) Conflict to Peace: Politics and Society in Northern Ireland over Half a Century. Oxford: Oxford University Press.

Horowitz D (1985) Ethnic Groups in Conflict, Oakland: University of California Press.

Horowitz D (2001) The Northern Ireland Agreement: Clear, Consociational, and Risky. In McGarry J (ed.), Northern Ireland and the Divided World. Oxford: Oxford University Press, pp. 89-108.

Jansen G, Evans G and De Graaf ND (2013) Class Voting and Left-Right Party Positions: A Comparative Study of 15 Western Democracies, 1960-2005. Social Science Research 42(2), 376-400.

Laver M (2001) Estimating the Policy Positions of Political Actors. London: Routledge.

Laver M and Garry J (2000) Estimating Policy Positions from Political Texts. American Journal of Political Science 44(3), 619-634.

McAllister I. (1983) Political Attitudes, Partisanship and Social Structures in Northern Ireland. Economic and Social Review 14(3), 185-202.

McCrudden C, McGarry J, O'Leary B and Schwartz A (2016) Why Northern Ireland's Institutions Need Stability. Government and Opposition: An International Journal of Comparative Politics 51(1), $30-58$.

McGarry J and O'Leary B (2004) The Northern Ireland Conflict: Consociational Engagements. Oxford: Oxford University Press.

McGarry J and O'Leary B (2006a) Consociational Theory, Northern Ireland's Conflict, and its Agreement. Part 1: What Consociationalists Can Learn from Northern Ireland. Government and Opposition: An International Journal of Comparative Politics 41(1), 43-63.

McGarry J and O'Leary B (2006b) 'Consociational Theory, Northern Ireland's Conflict, and its Agreement. Part 2: What Critics of Consociation Can Learn from Northern Ireland. Government and Opposition: An International Journal of Comparative Politics 41(2), 249-277.

McGarry J and O'Leary B (2009) Power Shared after the Deaths of Thousands. In Taylor R (ed.), Consociational Theory: McGarry and O'Leary and the Northern Ireland Conflict. London: Routledge, pp. 15-84.

McGlynn C, Tonge J and McAuley J (2014) The Party Politics of Post-Devolution Identity in Northern Ireland. British Journal of Politics and International Relations 16(2), 273-290.

Mitchell C and Tilley J (2004) The Moral Minority: Evangelical Protestants in Northern Ireland and their Political Behaviour. Political Studies 52(3), 585-602.

Mitchell P (1995) Party Competition in an Ethnic Dual Party System. Ethnic and Racial Studies 18(4), 773-796.

Mitchell P and Evans G (2009) Ethnic Party Competition and the Dynamics of Power Sharing in Northern Ireland. In Taylor R (ed.), Consociational Theory: McGarry and O'Leary and the Northern Ireland Conflict. London: Routledge, pp. 146-164.

Mitchell P, O'Leary B and Evans G (2001) Northern Ireland: Flanking Extremists Bite the Moderates and Emerge in their Clothes. Parliamentary Affairs 54(4), 725-742.

Mitchell P, Evans G and O'Leary B (2009) Extremist Outbidding in Ethnic Party Systems is Not Inevitable: Tribune Parties in Northern Ireland. Political Studies 57(2), 397-421.

Moore G, Loizides N, Nukhet AS and Lordos A (2014) Winning Peace Frames: Intra-Ethnic Outbidding in Northern Ireland and Cyprus. West European Politics 37(1), 159-181. 
Oberschall A and Palmer K (2005) The Failure of Moderate Politics: The Case of Northern Ireland. In O’Flynn I and Russell D (eds), Power Sharing: New Challenges for Divided Societies. London: Pluto Press, pp. 77-91.

O'Flynn I (2003) The Problem of Recognising Individual and National Identities: A Liberal Critique of the Belfast Agreement. Critical Review of International Social and Political Philosophy 6(3), 129-153.

O'Leary B (1995) Introduction: Reflections on a Cold Peace. Ethnic and Racial Studies 18(4), 695-714.

O’Leary B (1999) The Nature of the British-Irish Agreement. New Left Review 233, 66-96.

O'Leary B (2001) Comparative Political Science and the British-Irish Agreement. In McGarry J (ed.), Northern Ireland and the Divided World. Oxford: Oxford University Press, pp. 53-88.

O'Leary B, Grofman B and Elklit J (2005) Divisor Methods for Sequential Portfolio Allocation in Multi-Party Executive Bodies: Evidence from Northern Ireland and Denmark. American Journal of Political Science 49(1), 198-211.

Przeworski A and Sprague J (1986) Paper Stones: A History of Electoral Socialism. Chicago: University of Chicago Press.

Rabushka A and Shepsle K (1972) Politics in Plural Societies: A Theory of Democratic Instability. Columbus, OH: Charles Merrill.

Taylor R (2001) Northern Ireland: Consociation or Social Transformation? In McGarry J (ed.), Northern Ireland and the Divided World. Oxford: Oxford University Press, pp. 36-52.

Taylor R (2006) The Belfast Agreement and the Politics of Consociationalism: A Critique. Political Quarterly 77(2), 217-226.

Tilley J and Evans G (2011) Political Generations in Northern Ireland. European Journal of Political Research 50(5), 583-608.

Tilley J, Evans G and Mitchell C (2008) Consociationalism and the Evolution of Political Cleavages in Northern Ireland, 1989-2004. British Journal of Political Science 38(4), 699-717.

Tonge J and Evans J (2018) Northern Ireland: Double Triumph for the Democratic Unionist Party. Parliamentary Affairs 71(1), 139-154.

Tonge J, Evans J, Jeffery R and McAuley JW (2011) New Order: Political Change and the Protestant Orange Tradition in Northern Ireland. British Journal of Politics and International Relations 13, 400-419.

Wilford R (ed.) (2001) Aspects of the Belfast Agreement. Oxford: Oxford University Press.

Zuber CI (2012) Ethnic Party Competition Beyond the Segmented Market. Nationalities Papers 40(6), 927-944.

Cite this article: Tilley J, Garry J, Matthews N (2021). The Evolution of Party Policy and Cleavage Voting under Power-Sharing in Northern Ireland. Government and Opposition: An International Journal of Comparative Politics 56, 226-244. https://doi.org/10.1017/gov.2019.20 